\title{
Editorial \\ Electrorefining in Sustainable Metals Production
}

\author{
Jari Aromaa
}

check for

updates

Citation: Aromaa, J. Electrorefining in Sustainable Metals Production. Metals 2022, 12, 372. https:// doi.org/10.3390/met12030372

Received: 5 February 2022

Accepted: 14 February 2022

Published: 22 February 2022

Publisher's Note: MDPI stays neutral with regard to jurisdictional claims in published maps and institutional affiliations.

Copyright: (c) 2022 by the author. Licensee MDPI, Basel, Switzerland. This article is an open access article distributed under the terms and conditions of the Creative Commons Attribution (CC BY) license (https:// creativecommons.org/licenses/by/ $4.0 /)$.
Department of Chemical and Metallurgical Engineering, School of Chemical Engineering, Aalto University, P.O. Box 16100, FI-00076 Aalto, Finland; jari.aromaa@aalto.fi

\section{Introduction}

Electrorefining of metals was developed in the second half of the 19th century. The first application was the refining of copper, followed by the refining of gold and silver. Copper electrorefining was based on British patents issued to J.B. Elkington in 1865 and 1869. The world's first copper electrorefinery started production in 1869 at Burry Port in South Wales within the Pembrey Copper Works. The Wohlwill process to refine gold was invented in 1874 and the Moebius process to refine silver in 1884. The aim of these processes was to produce more pure metal that was possible with the available pyrometallurgical practices. Current practice is still to produce a moderately pure intermediate material that is refined to meet the final purity specifications for a metal. Electrorefining is the main method to produce very pure metals on a large scale, and it has been practiced commercially for cobalt, copper, gold, indium, lead, nickel, silver, and tin. Copper is the largest tonnage metal that is electrorefined.

Most of the metals can be deposited from fused salts, but commercial production is only for the more reactive ones. The metals that are produced commercially by molten salt electrolysis include the refractory metals, alkali metals, magnesium, and aluminum. Compared with common pyrometallurgical processes, the advantages of electrolysis are generally in the higher purity product. Electrolysis using molten salts is usually done by electrowinning, such as in the production of aluminum, but there are potential applications also in the electrorefining of metal scrap. The main limitation is in the cell designs that result in high cell voltages and large energy consumption.

Electrorefining using either aqueous solutions or molten salts is very efficient in producing pure metals because of the electrochemical potential differences of the produced metal and impurities. High-purity metals are needed in many applications, for example, copper in electrical engineering and nickel and cobalt in superalloys. For more sustainable metal production, the processes need development in energy consumption and in tolerance of more impure raw materials, such as waste materials and scrap.

\section{Contributions}

The research articles published in this Special Issue discuss electrorefining both in aqueous solutions and in molten salts. The paper by Aji et al. [1] discusses possibilities to increase production rate in silver electrorefining. An increase in current density will naturally increase the deposition rate, but it will also affect energy consumption. A process proposal known as high current density electrorefining could be operated at double the current density that is currently typical. This would mean a smaller plant area and smaller electrolyte volumes. The specific energy consumption could be at the same level as current practices. The paper of Wang et al. [2] is related to energy consumption in metal production. One of the factors that affects operational voltage and energy consumption is the conductivity of the electrolyte. The paper describes experimental models that can be used to estimate zinc electrowinning electrolyte conductivity. To increase conductivity, an increase in acid concentration and temperature are beneficial, whereas an increase in dissolved metal concentration has negative effects. The paper by Sahlman et al. [3] discusses the 
effects of nickel in copper electrorefining. The increasing anode impurity levels due to lower grade raw materials and increased recycling will require better process control to maintain product quality. The paper outlines mechanisms of nickel contamination and presents scenarios of what can happen during various stages of the electrorefining cycle.

The two papers that study molten salt electrolysis focus on titanium. The paper by Kwon et al. [4] describes a method that can be used in the recycling of titanium scrap. An electrorefining process using molten magnesium chloride was applied to titanium scrap to remove oxygen. This will facilitate further processing. In the paper by Wang et al. [5], titanium containing waste slag was electrolyzed to produce ferrotitanium alloys. A potential application of these alloys is hydrogen storage.

Demand for metals will continue to increase. Greater volumes and a wider range of metals and alloys will be needed for different purposes. The consumption of raw materials, energy, and water to produce metals will continue to rise on a global scale. Electrorefining and electrowinning are well-known methods to produce high-purity metals. They are also energy intensive, and methods to decrease specific energy consumption are continuously researched. All the papers in this Special Issue discuss certain details that belong to the Sustainability Development Goals 9, "Build resilient infrastructure, promote inclusive and sustainable industrialization and foster innovation", and 12, "Ensure sustainable consumption and production patterns". It is hoped that the ideas and results presented will promote further research in process improvement, especially in the area of circular economy and the recycling of metal-containing wastes.

Conflicts of Interest: The authors declare no conflict of interest.

\section{References}

1. Aji, A.T.; Aromaa, J.; Lundström, M. The Optimum Electrolyte Parameters in the Application of High Current Density Silver Electrorefining. Metals 2020, 10, 1596. [CrossRef]

2. Wang, Z.; Aji, A.T.; Wilson, B.P.; Jørstad, S.; Møll, M.; Lundström, M. Modelling the Effect of Solution Composition and Temperature on the Conductivity of Zinc Electrowinning Electrolytes. Metals 2021, 11, 1824. [CrossRef]

3. Sahlman, M.; Aromaa, J.; Lundström, M. Copper Cathode Contamination by Nickel in Copper Electrorefining. Metals 2021, 11, 1758. [CrossRef]

4. Kwon, N.; Byeon, J.-S.; Kim, H.C.; Heo, S.G.; Oh, S.J.; Choi, S.-h.; Seo, S.-J.; Park, K.-T. Effective Deoxidation Process of Titanium Scrap Using $\mathrm{MgCl}_{2}$ Molten Salt Electrolytic. Metals 2021, 11, 1981. [CrossRef]

5. Wang, B.; Chen, C.-y.; Li, J.-q.; Wang, L.-z.; Lan, Y.-p.; Wang, S.-y. Production of Fe-Ti Alloys from Mixed Slag Containing Titanium and $\mathrm{Fe}_{2} \mathrm{O}_{3}$ via Direct Electrochemical Reduction in Molten Calcium Chloride. Metals 2020, 10, 1611. [CrossRef] 